\title{
Multi-level governance through adaptive co-management: conflict resolution in a Brazilian state park
}

\author{
Barbara Schröter ${ }^{1 *}$, Karla Sessin-Dilascio ${ }^{2}$, Claas Meyer $^{1}$, Bettina Matzdorf ${ }^{1}$, Claudia Sattler $^{1}$, Angela Meyer ${ }^{3}$, \\ Gregor Giersch ${ }^{3}$, Camila Jericó-Daminello ${ }^{2}$ and Lukas Wortmann ${ }^{1}$
}

\begin{abstract}
Introduction: Communities situated in protected areas generate conflicts among park administrators, residents and scientists. Should they stay or should they go? This article presents a positive example of a community existing in a state park. The study describes the community's governance process as well as how the park administration and the community solve the conflicts that arise and achieve a method of co-management in a multi-level governance process.

Methods: The analysis is based on the Management and Transition Framework (MTF). We used a case study approach and collected data via document study, participatory observation and qualitative interviews.

Results: We find that the agreed system of community-based co-management has improved the implementation and enforcement of the state park's rules through negotiation and communication mechanisms in the park council. This relative success is due to the construction of social capital, equality and empowerment.

Conclusions: For state parks in similar situations, the findings suggest that: 1) a community should have at least a minimal level of self-organization; 2) the empowerment of the community in the decision-making process is useful; 3) the park administration should gain the trust of the residents; and 4) the effective management of ecosystem services can create a win-win situation for the community as well as the park.
\end{abstract}

Keywords: Management of ecosystem services; Social capital; Protected areas; Communities; Latin America

\section{Introduction}

Management of ecosystem services refers to the management of 'areas of various scales in such a way that ecosystem services and biological resources are preserved, while appropriate human uses and options for livelihood are sustained' (Brussard et al. 1998:10). Management of ecosystem services is a challenge that is often considered solved by creating a protected area. However, the opposite is frequently true, and the management of ecosystem services within a protected area can increase the challenge. The creation of protected areas has mainly been inspired by Yellowstone National Park, founded in 1872 in the USA. In contrast to the American model, however, park

\footnotetext{
* Correspondence: barbara.schroeter@zalf.de

'Leibniz Centre for Agricultural Landscape Research (ZALF), Institute of Socio-Economics, Eberswalder Straße 84, 15374 Müncheberg, Germany Full list of author information is available at the end of the article
}

management is often not officially planned by the state, and many parks remain so called 'paper parks' that exist only on paper (Bonham et al. 2008). Another problem that may not be considered in the planning phase is related to the management's activities: What should happen with the local communities existing within these new parks? The simplest solution to be considered is resettlement. However, in reality, resettlement is a difficult undertaking. On the one hand, the state often does not have enough resources for a resettlement process, and on the other hand, the members of the communities do not want to leave the land they have been living on for decades; therefore, the residents resist.

A solution to this problem can be found in adaptive co-management as a form of multi-level governance. In this type of governance mechanism, different social actors at different territorial levels such as the government 
(federal, regional and city governments), non-governmental organizations (NGOs) and international financial institutions share power and responsibility, which can prevent and solve conflicts (Benz 2010).

In this article, we present a case study of a protected area in Brazil where this type of multi-level governance through adaptive co-management has been applied. We intend to take a closer look at this multi-level governance process and particularly analyze why it is successful. Therefore, our research questions are:

- How does multi-level governance arise?

- How does multi-level governance support the management of the protected area with regard to the involvement of different social actors?

- What makes multi-level governance work in the complex context of a protected area?

There is strong evidence that the construction of social capital is an important factor in a successful adaptive co-management process (Pretty and Smith 2003; Plummer and FitzGibbon 2007). Therefore, in our case study, we attempt to verify the features of social capital proposed by Pretty and Ward (2001) and relate them to different phases of the process.

The literature on communities that are located inside protected areas is generally written from the perspective of conservationists (Brandon 1995) or anthropologists (Wood 1995; Diegues 1994; Diegues 1996; Dowie 2005). Only a few contributions advocate a balanced, differential perspective on the role of communities in protected areas. However, these studies mainly focus on the conflict between conservation and development (Abakerli 2001; Puppim de Oliveira 2002; de Souza Pimentel and Magro 2011; Jones et al. 2012; Nordlund et al. 2013). Other works focus on the communities' perception (Matta and Alavalapati 2006) or participation (Fraser et al. 2006; Suich 2013) but do not consider the context of a complex protected area. In contrast, this article examines the conflicts from an institutional point of view, focusing on the governance and management of a protected area. The identified governance process is co-management through a type of multi-level governance. Both concepts, comanagement (Berkes et al. 1991; Carlsson and Berkes 2005; Fabricius et al. 2007; Berkes 2009; Armitage et al. 2008; Bisaro et al. 2010) and multi-level governance (Berkes 2006; Paavola 2008; Pahl-Wostl 2009, Benz 2010; Basurto 2013), are widely examined in the literature and provide the theoretical basis for our analysis. However, fewer studies are available to outline the factors that make co-management even possible (Noble 2000; Pretty and Ward 2001; Pomeroy 2007; Geoghegan 2002; Sarrasin and Tardif 2012). This article contributes to filling this gap.
In studies on the management of protected areas in Brazil, the current issues of interest include the history of Brazilian conservation decisions (Rylands and Brandon 2005; Ferreira et al. 2001; Santilli 2005; Mittermeier et al. 2005), descriptions of the environmental laws, the conflicts related to humans living within the territory of protected areas (Diegues and Vianna 1995; Benatti 1999; Arruda 1999; Ferreira 2004; Parada 2004; Rylands and Brandon 2005; Diegues and Nogara 2005) and the effectiveness of protected areas (Lima et al. 2005; Ibama, WWF-Brasil 2007; WWF-Brasil, ICMBio 2012). Although some studies highlight conflict resolution (Rodrigues 2001; Campolim et al. 2008) and consider different theoretical management approaches (Morsello 2001; Vallejo 2002), the gap to be filled remains.

The article is structured as follows: First, we present the analytical approach and the key theoretical concepts and describe how we use them in our study. Next, we present our case study and some information about the data collection. Then we discuss our results. In the conclusion, we demonstrate that this case study can be an important example for state parks in Brazil and other countries. The administrators of other protected areas with similar problems can potentially learn from these management practices for ecosystem services and the factors that enable effective multi-level co-management.

\section{Methods}

Our analysis is based on theoretical approaches to multi-level governance, co-management and adaptive co-management. We use a case study approach for data collection, particularly through document study, participatory observation and qualitative in-depth interviews.

\section{Ecosystem management through multi-level governance, co-management and adaptive co-management}

We analyze management structures in the context of ecosystem services. Ecosystem services are defined as 'benefits people obtain from ecosystems' (MEA Millenium Ecosystem Assessment 2005). The concept of ecosystem services represents a variety of functions and services that can be derived from a certain ecosystem: regulation, habitat, production and information (de Groot et al. 2002; Constanza et al. 1997). In consequence, different values can be assigned to ecosystem services depending on individual perceptions and vested interests. In this sense, the concept is useful for our study, which investigates how these different values can be balanced through negotiation. As stated by Paavola, 'there is no compelling reason why the "catchments" of different benefit streams would coincide' (Paavola 2008:14). The main actors can contribute to the management of an ecosystem and its services.

In recent years, the concepts of multi-level governance, co-management and adaptive co-management have been 
further developed in the analysis of governance systems, especially for ecosystem management (Pretty and Smith 2003; Armitage et al. 2007). There is a wide range of definitions of co-management that are intended to distinguish it from similar concepts such as partnerships, collaborations (Plummer and FitzGibbon 2004), multistakeholder arrangements, policy networks, polycentric governance systems and epistemic communities (Berkes 2009:1693). Thus, we concur with Berkes and understand co-management as the 'sharing of power and responsibility between the government and local resource users' (Berkes 2009:1691). This definition is useful because it can be used to describe partnerships between different public, private and civil society actors, and it includes community representation and formal institutional arrangements for community participation in decision-making (Berkes 2009:1693).

Collaborative management, or co-management, demonstrates a level of participation 'characterized by (i) involving a wide range of stakeholders, (ii) an equal opportunity for participants to voice their concerns and influence the decision-making group, (iii) engaging participants in consensus building, and (iv) requiring a sustained commitment to problem solving' (Prager 2010:711; Margerum 2008).

A further development of the concept of co-management is adaptive co-management. Adaptive co-management is defined as 'a process by which institutional arrangements and ecological knowledge are tested and revised in a dynamic, ongoing, self-organized process of learningby-doing' (Berkes 2004:9); adaptive co-management includes the dimension of social learning. It is important that the participating actors in a co-management process have different types of ecosystem knowledge (both scientific and experiential knowledge) and that these actors work at different ecological scales and levels of decisionmaking. In an ideal case, bridging organizations, such as NGOs, for example, can serve as intermediates between the different levels (Plummer and FitzGibbon 2007; Schultz et al. 2011).

Multi-level governance is a good concept to be followed here because it refers to steering and coordinating the interdependencies between different territorial levels based on negotiation or competition through the cooperation of public and private actors who are embedded in an institutional rule-making system within each level (Benz 2010). In this study we examine these different levels to understand the governance system as a whole because there are institutions (rules) and actors on different levels that contribute to the governance process. Although multi-level governance brings together the different levels in a case of environmental governance, its definition can be quite confusing and incomplete when we include the relationship between local communities and the government. Thus, to perform an all-encompassing analysis of the complex management situation we wish to analyze, we follow Berkes et al. (1991) and understand multi-level governance as co-management.

To analyze these complex multi-level governance structures, the Management and Transition Framework (MTF) developed by Pahl-Wostl et al. (2010) appears to be beneficial. The MTF is based on the concepts of adaptive management, social learning, the transformation process and the Institutional Analysis and Development (IAD) framework (Ostrom 2005). Here, we use the MTF to map the management process as a sequence of action situations (AS) at different administrative levels. These action situations are linked either by institutions (I), knowledge (K) or operational outcomes (OO). The MTF considers learning cycles in three management phases: 1) problem structuring and reframing; 2) developing an action plan and mobilizing additional support; and 3) implementing and evaluating pilots or experiments (Pahl-Wostl et al. 2010).

\section{Case study description}

Cardoso Island is located on the Lagoon-Estuarine Complex of Paranaguá-Iguape-Cananéia in the Ribeira Valley Region at the border between the State of São Paulo and the State of Paraná, Brazil. It has an area of 22,500 hectares and contains the largest region of continuous Atlantic Forest biome, holding more than one-third of the remaining forest in the State of São Paulo, particularly mangroves, a sensitive ecosystem with huge biodiversity.

There are six communities located inside the Ilha do Cardoso State Park (Parque Estadual da Ilha do Cardoso, PEIC) that administratively belong to the municipality of Cananéia (see Figure 1) One of these communities is Marujá. Today, approximately 60 families live there, comprising approximately 180 people. The residents are traditional 'Caiçara'. Caiçaras are an ethno-cultural mixture of indigenous people, Portuguese colonizers and, to a lesser extent, African slaves. Geographically, the Caiçaras are distributed along the Brazilian coastline between Rio de Janeiro and Paranaguá. Their way of life is based on itinerant agriculture, small fishing activities, the extraction of plants and the construction of handicrafts. The culture has traditionally been considered sustainable because the population's economic activities were poor and the people produced goods for their own consumption. Because they were living in the park, the residents were forbidden to use its natural products. Therefore, today, the residents earn their income from tourism (from hostels and campgrounds) during some holidays in the summer months. In the winter, there are much fewer tourists. Approximately half of the families complement their income with these activities. The residents use fishing to complete their diet.

Since the creation of the park in 1962, tourist visits in the region have become more and more numerous. 


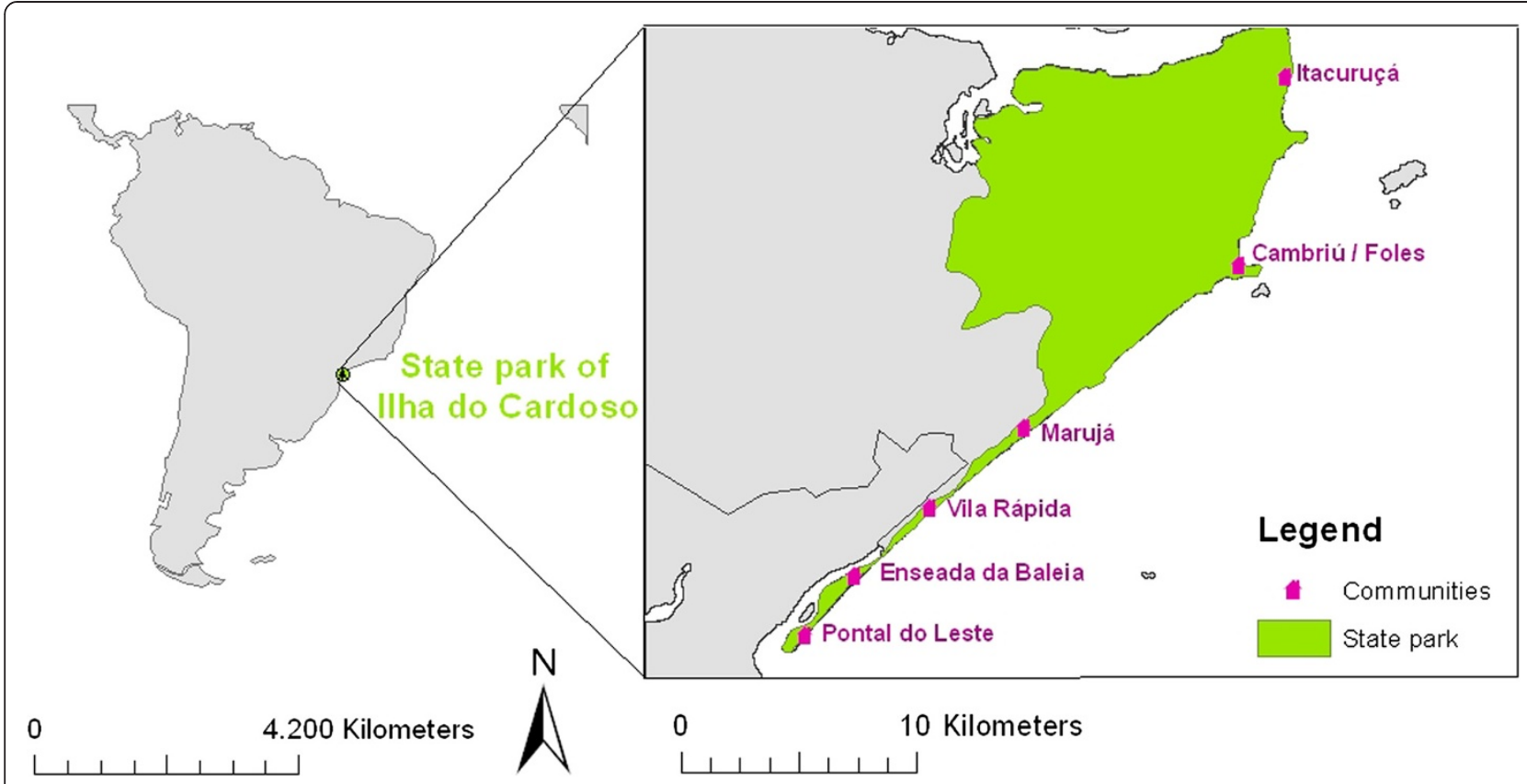

Figure 1 Location of Parque Estadual da Ilha do Cardoso (PEIC) on the map of Brazil. The map focuses on the location of the PEIC and its six communities. Source: authors' own elaboration based on data from D-Maps (http://d-maps.com) and Diva-Gis (http://www.diva-gis.org/gdata)

The construction of Highway BR-116 (Régis Bittencourt), linking major centers to the region of Lagamar, reinforced this process. The growth of tourism increased migration to the region and triggered land speculation. Therefore, pressure on the residents grew, caused by uncontrolled construction and the building of summer tourist residences, real estate speculation (Gadelha 2008) as well as plans for a luxury spa. The effects of tourism such as camping brought environmental dangers to the Marujá community because there was no real capacity to host the influx of people. Waste and sewage became too much for the existing systems, and the number of houses built on sandbanks in the mangrove areas increased dramatically, leading to environmental degradation.

\section{Data collection in the case study area}

Data collection for the analysis included document study, participatory observation and qualitative interviews. The document study concentrated on the analysis of documents, mainly from the park administration.

For the analysis of the council, we studied the council by-laws and the minutes of the council meetings from its creation in 1998 until the present. Altogether, 150 council minutes, starting with the council meeting on 25 March 1998 and ending with the council meeting on 27 November 2012, regarding rules enforcement and implementation by the council were analyzed and used to describe the governance process.

Participatory observation was performed to complete the document study. Participatory observation is mainly important to get access to the field, to understand the perspective of the observed actors and to identify their patterns of action (Fenno 1986, cited following Schöne 2005). During this phase, community members were accompanied in their daily lives and activities, for example, in meetings, talks, and workshops, among others, as well as in situations where they interacted with the local stakeholders and in internal meetings. The findings and information gathered via participatory observation were complemented by qualitative interviews and informal talks with the stakeholders in each case study.

Data collection included 28 semi-structured, face-toface interviews conducted in the communities of Marujá and Cananéia. Eighteen of the interviews were conducted with community members, and of these, seven of the interviews were conducted with people who have or had some functional posts in Maruja's community organization, Associação dos Moradores do Marujá (AMOMAR); therefore, those community members had a double affiliation and were asked about some extra topics regarding the association. Seven interviews were conducted with staff from the park administration, including two former park directors and five people in charge of monitoring activities. Finally, three experts from the academic and civil society fields were interviewed. None of the administrative or expert interviewees were members of the community. In general, the interviewees were chosen by their importance as stakeholders in the governance model, or, sometimes via snowball sampling, interviewees were chosen by following 
the advice of already-interviewed people. All of the interviews were conducted in Portuguese using interview guidelines, and the interviews were recorded with the consent of the interviewees, transcribed into Portuguese and then translated into English. The interviews generally lasted between 20 and 120 minutes and were conducted in or near the residents' houses, in the respective offices of the administrative staff, or in public spaces nearby. The transcripts were examined to determine the factors that likely contribute to successful ecosystem management. Therefore, the interviews were coded with the software MAXQDA according to the keywords described in the section 'enabling factors for multi-level governance'.

\section{Results}

\section{The governance process}

Following the MFT, the PEIC governance process can be split into three management phases: 1) problem structuring and reframing; 2) development of an action plan and mobilization of additional support; and 3) implementation and evaluation of pilots or experiments. Each phase is characterized by a variety of action situations and multiple levels of institutions and organizations that either influence each phase or create an outcome. In Figure 2, an overview of the involved institutions and organizations as well as their relationships is displayed.

\section{Phase 1: problem structuring}

During phase 1 , the main action situations were: a) the park's creation and management at the state level; and b) the community's self-organization at the community level.
Park's creation and management at state level The park was created in 1962, but the management of the park was not transparent until the 1980s. Before the 1980s, a manager could act as he saw fit; there were no formal park rules. During the 1970s, the belief was that research centers (such as Centro de Pesquisas Aplicadas de Recursos Naturais da Ilha do Cardoso, CEPARNIC, and the still-existing Nucleo Perequê) could manage the park; however, this system did not work because of the centers' poor infrastructure. The park was under the formal administration of the Forest Institute (Instituto Florestal, IF), a subordinated research body of the Environmental Department (Secretaria de Meio Ambiente, SMA) of São Paulo State, which was founded in 1886 to guarantee natural conservation. The administration was top-down and did not consider social actors. No meetings with the communities were offered.

Community's self-organization at community level Despite not being consulted, the Marujá community began to hold its own meetings (assambléias) with the aim of discussing the increased problems with external impacts such as the presence of summer tourists, new construction activities and the organization of the tourism industry. Until the creation of AMOMAR in 1998, these meetings were informal.

The conflicts between the PEIC and the communities at the local and state levels became evident when Brazil's environmental laws were changed. These changes led to phase 2 .

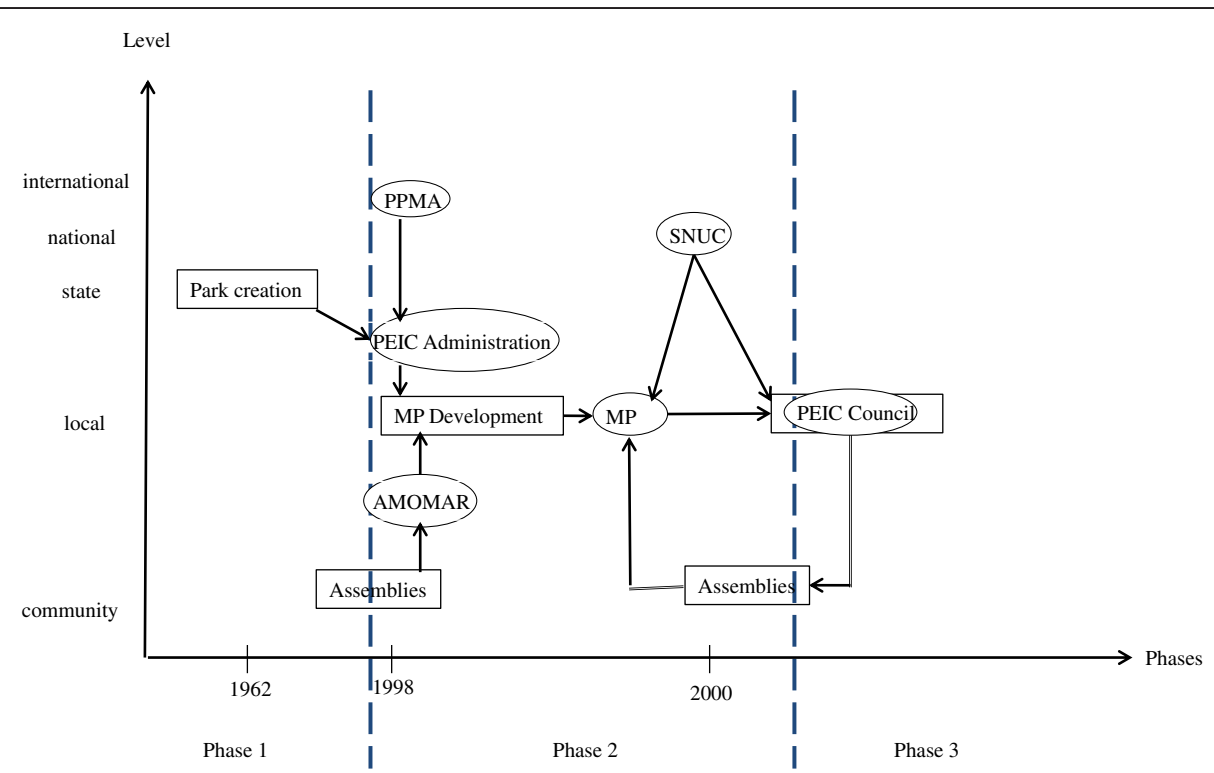

Figure 2 Governance processes for the Parque Estadual da Ilha do Cardoso (PEIC). Source: authors' own elaboration, adapted from PahlWostl et al. (2010:578). AMOMAR, Associação dos Moradores do Marujá; MP, management plan; PEIC, Parque Estadual da Ilha do Cardoso; PPMA, Programa de Proteção da Mata Atlântica; SNUC, Sistema Nacional de Unidades de Conservação. 


\section{Phase 2: development of an action plan and mobilization of additional support}

Phase 2 (see Figure 2) included two main action situations: a) the development of the management plan; and b) the installation of the park council (developed from the management plan). The latter played a key role in c) the implementation of the management plan and the development of more rules for the park. The institutionalized community association was involved in all three of these developments at the community level. The park administration was involved at the local level, and the management plan was supported by a forest protection program as well as by national legislation on conservation at the national and international levels.

Development of the management plan Driven by international events during the 1980s and 1990s, environmental conservation became an important topic in Brazil. From 1988 onward, politicians, scientists and members of the civil society developed the National System of Conservation Units (Sistema Nacional de Unidades de Conservação, SNUC). The SNUC combined much of the existing legislation on protected areas, called Conservation Units (Unidade de Conservação, CU), created a classification system and established new norms for each classification type.

The CUs were divided into two categories: Integral Conservation Units (Unidades de Conservação Integral) and Conservation Units for Sustainable Use (Unidades de Conservação de Uso Sustentável). The first category permits only the indirect use of the ecosystem for activities such as research and visitation (both only with permission) and does not accept human intervention in the ecosystem. The second category accepts the sustainable use of natural resources and human intervention. As a state park, the PEIC belongs to the first category.

The SNUC was finally approved in 2000 by Federal Law number 9.985/00. It brought two major changes for the PEIC and other protected areas: all of the CUs were required to establish a management plan (Article 27) and the Integral Conservation Units were additionally required to create a consultative council (conselho consultivo) (Article 29). The management plan for the PEIC was developed within the scope of the Program for the Protection of the Atlantic Rainforest (Programa de Proteção da Mata Atlântica, PPMA), which was financed by the German Kreditanstalt für Wiederaufbau (KfW) and some public money. This international cooperation helped to encourage the development of the management plan because it was a condition for receiving money from the program. Moreover, the idea to finance the management plan via a program was new.

The community participated in developing diagnostic reports for the management plan that included technical, institutional and participatory data gathering and analysis.
During the participatory management plan meetings, the main problems were discussed by the interested parties regarding: 1) the use of natural resources (forest products and fish) as well as areas to be used for agriculture; 2) the organization of the tourism industry (bars, hostels, campgrounds, trails, monitors and transportation); 3) questions about property; and 4) the presence of indigenous people.

Implementation of the park council To encourage the participation of the local society in the process, the management plan created the Support Committee for the PEIC Administration (Comitê de Apoio à Gestão do PEIC).

According to the SNUC, the council defined itself as a consultative committee that supports the PEIC administration. The council was designed to encourage cooperation among the municipal, state and federal public entities. Therefore, the council was composed of representatives from the public entities, the civil society organizations, the environmental police, the churches and the traditional communities that interacted with the park. Its main objectives were to guarantee the continuous participation of the public institutions, civil society organizations and the traditional communities located in the park (adaptive co-management) in the follow-up and execution of activities foreseen in the management plan.

In addition to the formal rules on the park council's functions, informal rules on processes and procedures were developed. The council was consultative, not deliberative, but the members made decisions by vote, and the park director respected those decisions. 'Consideration is an institutional pro forma, but if the council is strong and participatory, its forwarded proposals have good chances to be followed by the institution' (former Park Director 1).

Implementation of the management plan The first task for the council was to implement the programs established in the management plan. To achieve this goal, the park administration first negotiated the rules with the communities, and then the council discussed the results and made its final decision. The clearest example of this process came with the organization of public visitation to the park, which caused the most problems for the community of Marujá. Through participatory planning and management, the concept of sustainable tourism was established.

During the implementation process, other problems arose, and new topics were included in the management plan, such as real estate regulations, garbage and sewage disposal, the regulation of domestic animals, rules for summer operations, and conduct adjustment terms. These new topics had to be matched with the issues that were already established in the management plan. The 
co-management process that had been initiated with the management plan had passed to adaptive co-management.

\section{Phase 3: ongoing process: implementation and monitoring}

The development of the management plan to the current state of tourism in the park took approximately ten years. The efforts of the park council in terms of rule implementation and conflict resolution are still ongoing. Today, the main action situations are council meetings where actors from the local and community levels come together to discuss and solve new problems. If necessary, the council consults with the community meeting.

\section{Enabling factors for multi-level governance}

We tested the four social capital features of Pretty and Ward (2001) to determine the factors that make multilevel governance work in the complex context of a protected area.

\section{Common rules, norms and sanctions}

The outcome of phases 2 and 3 were common rules, norms and sanctions for the park management. The park rules differ in terms of their nature, importance, and to whom they are addressed.

\section{Formal rules}

The most discussed formal rules concern the construction and renovation of houses. These activities are essentially not allowed. Residents and builders must request authorizations from the park council and the Forest Foundation in São Paulo. Therefore, if the residents want to change a window or door, add a bathroom or some other type of room, build a snack bar to sell food, or construct a house for new family members, they must ask for authorization. For the residents, this process can be annoying. 'If I would like to construct, the park does not allow it because of deforestation, and the toilet . . . as everything will run into the sea. It is not like before' (Resident 7).

A further set of formal rules attempts to improve the negative effects from settlement and tourism. The most discussed rules in the interviews were the restrictions on camping, tents, rooms and guests. Domestic animals such ascats and dogs are not allowed on the island for residents or tourists. There is also a certain time when noise is not allowed. In addition, only traditional residents are allowed to stay on the island (they cannot be absent for more than one year and one day). Tourists can stay up to three months.

In general, all of these rules are respected by the residents of the park and the tourists. As noted previously, the community itself participated in the formation of the rules on the organization of tourism together with the park administration.

\section{Informal rules}

There are also some informal rules that are widely accepted by the actors. The payment of small taxes was often discussed in the interviews, for example, taxes for water, camping, the hostels (per guest per day) and the public telephone. Another informal agreement is that the residents can take some natural material for artwork. These works, such as mobiles and curtains, are mainly made out of seashells, but they sometimes contain some knops or seeds. The line where extraction is allowed is thin because these items can also often be found on the ground. Some residents agreed that these rules are needed: 'Not big things, small things that you are not allowed to do. Suddenly you open a trail to the beach, small things that, if you would ask for them they would be denied, and if they would not be denied, they would take between ten months and one year to give you the permission' (AMOMAR Member 7).

\section{Sanctions}

If the residents do not follow the rules, sanctions are applied. There are two possible sanctions, the Conduct Adjustment Term and the Law on Environmental Crimes (Law number 9.605/98); which rule applies depends on the level of damage. For the community, the most important sanctions are fees and reductions in the number of allowed tents set by AMOMAR. Such sanctions result when the allowed number of tents for lodging tourists is not respected by the residents.

\section{Relations of trust}

Cooperation with the park administration was not always easy and free of conflict, and some management activities took a long time to be implemented. However, cooperation was possible because of a good relationship with the park director who initiated the implementation of the management plan. The park director supported the communities located in the park and negotiated with the residents in the frequent case of opposing opinions. The park director gave the residents a chance to express themselves and always solicited their participation.

Therefore, the council meetings were always held in different communities so all of the residents had a chance to participate. The park director not only sat on the park council, but he also gave the council some value because he tried to have the Forest Institute accept the council's decisions. Thus, besides being dynamic and proactive, the park director was perceived as if he 'fight[s] as he was a member of the community himself' (Marujá Resident 2) and was 'more courageous' (Marujá Resident 7). The park director was very close to the community and its residents, not only because he often visited the communities in the park but also because he stayed as director for approximately ten years. 
In comparison, the other directors before and after the term of the referenced park director stayed in the position for an average of two years and hardly ever visited the communities in the park. 'He was staying some time here and he also took time with more liberties to decide. He had a big influence on the residents. He worked together with them, was looking after the communities more and opened spaces for the communities to talk' (Park Administration 2).

Thus, through his conduct, the long-term park director was able to build relations of trust with the community that made negotiation and cooperation possible. In contrast, the other park directors did not grant the same value to the decisions of the park council. These park directors did not implement the decisions of the park council, or they made decisions on their own but they did strictly follow the institutional requirements, that is, they respected the decisions of the Forest Institute. For the residents, these attitudes led to the impression that the other park directors did nothing for the park and impeded the development of trust with the residents.

\section{Reciprocity and exchanges}

There is a kind of exchange between the community and the park administration. The community supports the park in ecosystem conservation and monitoring, while the park supports the community in achieving economic benefits. Thus, there are special obligations and certain gains for both sides.

On the one hand, the community must accept the rules of the park, which are focused on the number of tourists and the prohibition of large construction projects and housing additions. The residents must accept the capacity limits of the park and the status quo of their living conditions. They are also forced to accept a certain loss of their culture through restricted fishing and agricultural activities.

On the other hand, the community achieves some real gains from the park. Because of the management plan, ecosystem conservation is controlled, and the Brazilian society has become more aware of the park's problems. The park is still in good environmental shape, and the community is expected to remain. Because the residents participated in the development of the management plan, they were able to negotiate the rules, eliminate the summer homeowners, and formally claim and secure their rights as traditional residents. The park council plays a role in institutionalizing these participatory negotiations.

The park administration does not have enough resources to monitor the activities of the tourists or the residents, and it is not able to provide infrastructure improvements to the residents. Therefore, the park gains from the support of the community in monitoring, self-control and nature conservation. The community observes the tourists, and if they 'see people doing the wrong things' (AMOMAR Member 3), they report them to the park administration, the park guards, the police or the monitors. This process preserves nature beyond just the impact of the residents and the tourists. For example, the residents clean the beach of foreign waste that washes ashore from large ocean tankers. The park administrators appreciate this behavior. 'I know some parks that do not have a community and they put two park guards there to look after it, but everybody succeeds in entering the park, making a mess there and devastating the park. Here it is not like this. The community itself is controlling' (Park Monitor 2).

\section{Connectedness in networks and groups}

AMOMAR acts as an intermediate between the community and the park administration, representing the community on the council and fulfilling and securing the monitoring tasks for the park administration. The residents have a chance to participate in discussions about park issues and have their interests represented through the council. 'AMOMAR is defending the people of Marujá' (AMOMAR Member 2). As written in its bylaws, AMOMAR's aims are to allow the traditional peoples to stay in the park, to improve their quality of life and to conserve the park as it is. Because of AMOMAR's success, 'we have a name such that people respect the representation of AMOMAR. The PEIC administration, the state, and the municipality of Cananéia respect us more' (AMOMAR Member 1).

In reality, all of the residents are represented by AMOMAR, although most of the residents perceive that the real members are only those on AMOMAR's board of directors. Although the board of directors meets once per month, the residents participate in meetings that take place once each year or at other times when urgent issues must be resolved. Additionally, the interviewees noted participation by the community in the management plan workshops and on the park council.

By bringing together the community members, AMOMAR facilitates the work of the park administration and decreases the administration's responsibilities.

Besides the four factors identified by Pretty and Ward (2001) we found two more that support social capital: equality and empowerment.

\section{Equality}

While participation in AMOMAR represents a chance for every resident to voice their opinion and influence the decision-making process, the association also helps to improve economic equality, which is an important precondition for the building of social capital. 
The socioeconomic situation of the residents of Marujá is not equal. There are some richer and some poorer residents. Above all, there is a division between Marujá 1, the center with a larger tourist infrastructure such as hostels and restaurants, and Marujá 2, where tourists mainly rent spots in campgrounds. However, the reorganization of the tourism industry, such as the redistribution of campsites, at least represents an attempt to create equality through tourism. Tourists are distributed equally via the community telephone which they use to make inquiries about where to visit. Taxes differ, and people who house more tourists or have more family members pay more. Finally, some equality can be guaranteed through internal controls and sanctions. However, competition always remains between the families for one important resource: the tourists.

\section{Empowerment}

Opinions on the influence of the community in the administration of the park differ. These opposing opinions reflect an ambivalence regarding the use of the park council as a deliberative or consultative body. AMOMAR had a chance to participate in the development of the management plan, but not in a decisive role. Within the park council, AMOMAR can discuss its objectives and either cooperate or try to put pressure on the rest of the park council by channeling the requests of the residents. The fact that the park administration listens to the residents' problems within a formal decision-making framework empowers the local people. They feel they are taken seriously, and they gain self-confidence by actively participating in the management process. 'The community has quite a lot of influence because it is working together with the park, basically in the meetings with the council' (Marujá Resident 2).

\section{Social capital linked to the governance process}

Certain factors can be assigned to different phases of the governance process, as seen in Figure 3.

Trust was earned in phases 1 and 2 regarding the negotiation and development of the management plan. Institutions such as AMOMAR and the park council establish the connectedness of networks and groups as well as equality in all of the phases and guarantee the implementation and continuation of the governance processes. Common rules, norms and sanctions as well as reciprocity and empowerment can be observed in the implementation phase and as an overall outcome of the governance structures.

\section{Discussion}

The presented form of community-based, multi-level comanagement at the PEIC improved the implementation and enforcement of the state park's rules. Our results show that the reasons for this success include agreeing to the rules at all levels, the trust that was built through mutual recognition of the stakeholders, valuable exchanges between the levels, the networks and groups based on AMOMAR and the park council that connected at different levels, the equality of participation in governance and the improvement in economic equality among all of the stakeholders, and the increased empowerment at the community level. Although the methodology used in this study, that is, a quantitative analysis of one single case study, is limited, the results confirm the findings of Pretty (2003) and Pretty and Ward (2001). If success in management of ecosystem services is defined as cooperation on the implementation and enforcement of the rules, the identified factors are present.

In addition to the actor-centered findings, we can also confirm the findings from the multi-level governance literature regarding the importance of institutions (Fraser et al. 2006; Prager 2010). On the one hand, the rule-making and rules enforcement process demonstrated the importance of institutionalized bridging organizations at different stages of the management process. On the other hand, the rules were proven to be essential. The SNUC legislation was developed during the implementation of the management plan, and once it was approved, the legislation supported the decisions of the PEIC through the management plan and the park council. Additionally, formal international help through the KfW also helped the institutionalization and negotiation process. However, the existing management at the community level through AMOMAR was a precondition for the success of the institutionalization process, especially in comparison with the other, less organized communities in the park. Thus, both top-down and bottom-up agreements had to occur at the same time to make the co-management processes possible.

In the Brazilian context, the findings from this case study are relevant if we look at other park management situations. Brazilian CUs have a number of administrative resource problems: lack of staff, lack of financial resources, legal irregularities and problems with territory delimitation. Even when the CUs' administrative resources are sufficient, they can still suffer from poor management choices, a lack of embedded staff in the management process and bureaucratic problems. Although participatory processes through councils are required by law, they do not always take place, and the relevant social actors are not always involved (Bensusan 2006; Brito 2003).

To summarize some of the lessons learned from this case study that can help in similar cases of conflicting management of ecosystem services such as in cases of communities located in state parks, we can conclude that a management plan alone is not sufficient; instead, participatory management must become an institution, similar to the park council in this case study. Rules enforcement works through the negotiation and communication 


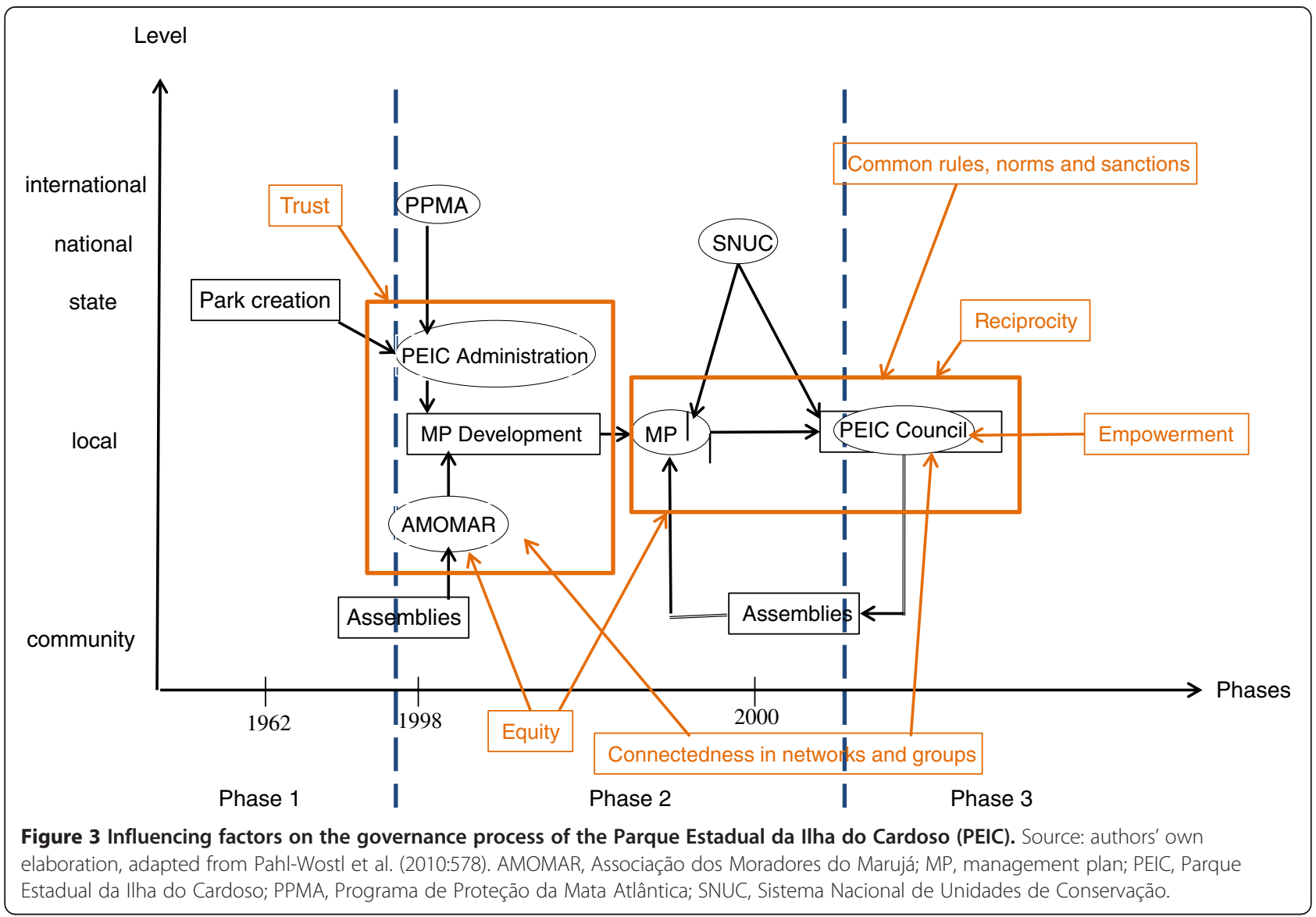

mechanisms developed in the park council. In these negotiations, a win-win situation is created. The community must remain in the park and support the park in the enforcement of its rules. For such a negotiation and communication process to work successfully, it is useful if the community has at least a minimal level of selforganization. The other communities in the park in this case study lack this minimal level of organization, and therefore collaboration with these communities in the council is weaker. It is useful for the park administration to strengthen the community and consider it in the decision-making process by sometimes ceding responsibility to the community, thereby contributing to the community's self-confidence and empowerment. Finally, personal trust among the actors is also necessary so the park administration can be represented by one visible person.

Nevertheless, the presented solution is strongly linked to the status quo and is sensitive to changes in the system. If one of the components of the system fails, new conflicts may arise. This possibility leads to the question of the advantages and disadvantages of a change in the CU category which would open another field for investigation to consider a completely different array of aims, rules and participatory processes to enhance conservation.

\section{Conclusion}

In this paper, we studied, analyzed and evaluated communitybased management of ecosystem services in a special situation: a community located within a state park in Brazil. Every state park must develop a management plan and appoint a consultative park council. The implementation of both of these instruments is complicated because they often do not exist or do not work properly. Our case is a positive exception that includes a functioning community and park administration. Good management was achieved through cooperation in terms of the enforcement and implementation of park rules through participatory management, the development of a management plan, and a working park council. Social capital factors demonstrate that social capital was fortified in this process and was a precondition for successful management. The community's participation in the application of the rules and the sanctions contributed to the empowerment process. Formal and informal rules were negotiated between the park administration and the community to ensure a win-win situation for both parties, demonstrating reciprocity. This process led to the development of trust, especially through the work of the park director. On the one hand, the management process fostered connectedness with the community through the community's participation on the park 
council. But on the other hand, the fact that the community was already organized through AMOMAR also fostered this participation. In conclusion, this case study presents a significant theoretical example because it supports adaptive co-management in multi-level governance. This case study can help other Brazilian CUs with their future management choices.

\section{Abbreviations}

AMOMAR: Associação dos Moradores do Marujá; AS: Action situation: CEPARNIC: Centro de Pesquisas Aplicadas de Recursos Naturais da llha do Cardoso; CU: Unidade de Conservação; I: Institution; IAD: Institutional Analysis and Development; IF: Instituto Florestal; K: Knowledge; KfW: Kreditanstalt für Wiederaufbau; MP: Management plan; MTF: Management and Transition Framework; NGO: Non-governmental organization; OO: Operational outcome; PEIC: Parque Estadual da llha do Cardoso; PPMA: Programa de Proteção da Mata Atlântica; SMA: Secretaria de Meio Ambiente; SNUC: Sistema Nacional de Unidades de Conservação.

\section{Competing interests}

The authors declare that they have no competing interests.

\section{Authors' contributions}

BS and KSD participated in the design of the study and the data collection, performed the analysis and interpretation of the data and drafted the manuscript. CM, CS, BM, AM and GG made important contributions to the concepts and critically revised the manuscript. LW participated in the coordination and revised the manuscript. CJD supported the data collection. All of the authors read and approved the final manuscript.

\section{Authors' information}

BS studied political science with a focus on Latin American politics at the Eberhard Karls University of Tübingen, Germany. She earned her doctoral degree from the Bavarian Julius-Maximilian's University of Würzburg, Germany, with a thesis titled 'Clientelistic Structures in the Mexican Political Parties: A Comparison of PRI, PAN and PRD'. After finishing her PhD, she worked for a public opinion research company in Mexico City, Mexico. Since November 2011, she has been with the Leibniz-Centre for Agricultural Landscape Research (ZALF). Her current research priorities include the investigation of governance models, institutions, institutional theories and civil society organizations in Latin America.

KSD graduated in 2010 with a degree in biological science from the University of São Paulo (USP), Brazil, and is a Master's student of environmental sciences at USP (PROCAM-USP). Her research focus is better management options for Conservation Units.

CM studied law at the University of Osnabrück, University of Milan and Humboldt University in Berlin, Germany. He completed his legal training at the Berlin District Court of Appeals. He holds a Master's degree in integrated natural resource management from the Institute of Economics and Social Sciences of Agriculture at Humboldt University in Berlin, and is a PhD candidate. His work is focused on inter- and trans-disciplinary environmental research, environmental governance, agri-environmental policy, institutional economics and the economic analysis of law.

BM holds a Diploma in landscape planning, which she received from the Technical University of Berlin. She earned her doctoral degree in the interdisciplinary graduate program of integrative environmental assessment at the Ecology Centre of the University of Kiel, Germany. BM has been working at the Institute of Socio-Economics at ZALF since 2002, leading the research area of instruments and institutions of ecosystem service management. Her research focus is on the evaluation and development of instruments and institutions for sustainable development, with a specific focus on payment for ecosystem services (PES). She has specialist expertise in environmental economics and instruments of sustainable development and long-term experiences in interdisciplinary environmental research. CS holds a Diploma in horticultural science from the University of Hanover, Germany. She earned her PhD in 2008 in agricultural science at the Institute of Economic and Social Sciences of Agriculture, Humboldt University of Berlin, Germany. For her PhD thesis, she focused on the model-based assessment of the ecological impacts of agricultural farming practices and performed an analysis of farmers' acceptance of more environmentally friendly production alternatives in their practices. Her research interests include the use of decision support systems in the environmentally friendly management of agricultural ecosystems, modeling the ecological effects of land use practices, processing uncertain knowledge in modeling based on fuzzy logic, the sustainability and multi-functionality of agriculture, and the provision of ecosystem services in agriculture.

AM is a member of the board of directors of the Organisation for International Dialogue and Conflict Management (IDC). She holds a PhD in political science/international relations from the Institute of Political Studies (Sciences Po, Paris, France) and the University of Vienna, Austria (co-tutelle de thèse). She has participated in several international projects and has been the Coordinator of SustainergyNet and Cambiodiversity. As a political scientist, her research interests include the involvement of civil society in research and policy processes, sustainable development and regionalization processes in developing countries.

GG is a PhD candidate and lecturer at the Institute of Political Science, University of Vienna. He holds a Master's degree in political science (Master's thesis on international relations on private military companies) after studying at the University of Vienna and at the Institute of Political Studies (Paris). He has contributed to a wide range of national and international projects, including Agrofolio, Diverseeds and SustainergyNet. His research focus is on sustainable development, micro-finance and innovative approaches to the local economic value chain.

CJD holds a Bachelor's degree in biological sciences and is currently undertaking a Master's course in the interdisciplinary program PROCAM-USP. Her major interests are related to different methods of environmental evaluation of ecosystem services. She is also participating in different projects such as the evaluation of the costs and benefits of a federal hydroelectric project in the Tapajós River in the Amazon region and the establishment of a PES policy in São Paulo State.

LW holds a Diploma in geography, economics and political science. He studied at the Friedrich-Schiller-University of Jena, Germany, Free University of Berlin and Pontifical Catholic University of Rio de Janeiro, Brazil. He has a regional focus on Brazil, where he worked for the Deutsche Gesellschaft für Internationale Zusammenarbeit (GIZ) in the area of rural development projects. Before his engagement at ZALF, he worked for three years for an Austrian consulting company, where he conducted studies and evaluations for the European Commission and gained experience in project management for international project consortia.

\section{Acknowledgements}

We thank the park administration, the Forest Foundation (Fundação Florestal, FF) and the Coordination Office of Environmental Technical Information, Documentation and Research (Coordenadoría de Informações Técnicas e Pesquisa Ambiental, COTEC) for access to data and field support. We also thank the Marujá community for its warm welcome and willingness to support our investigation and constantly respond to our questions and doubts.

This research has been funded by the 7th Framework Program of the European Union in the project CiVinet, the capacity of civil society organisations and their networks in community-based environmental management, under contract ID: 282750.

Finally, we would like to thank two anonymous reviewers who provided very helpful comments on an earlier version of this paper.

\section{Author details}

'Leibniz Centre for Agricultural Landscape Research (ZALF), Institute of Socio-Economics, Eberswalder Straße 84, 15374 Müncheberg, Germany. ${ }^{2}$ Instituto de Eletrotécnica e Energia (IEE) da Universidade de São Paulo (USP), Serviço Técnico Acadêmico, Secretaria de Pós Graduação, Avenida Professor Luciano Gualberto, 1289, Cidade Universitária, 05508-010 São Paulo, SP, Brazil. ${ }^{3}$ Organisation for International Dialogue and Conflict Management (IDC), Kaiserstrasse 50/6, Vienna 1070, Austria.

\section{Received: 1 October 2013 Accepted: 10 February 2014} Published: 28 February 2014

\section{References}

Abakerli S (2001) A critique of development and conservation policies in environmentally sensitive regions in Brazil. Geoforum 32:551-565 
Armitage D, Berkes F, Doubleday N (2007) Introduction: Moving Beyond Co-Management. In: Armitage D, Berkes F, Doubleday N (eds) Adaptive Co-Management: Collaboration, Learning and Multi-Level Governance. UBC Press, Vancouver, pp 1-15

Armitage D, Marschke M, Plummer R (2008) Adaptive co-management and the paradox of learning. Global Environ Change 18:86-98

Arruda R (1999) "Populações tradicionais" e a proteção dos recursos naturais em unidades de conservação. Ambiente \& Sociedade 5:79-92

Basurto X (2013) Linking multi-level governance to local common-pool resource theory using fuzzy-set qualitative comparative analysis: insights from twenty years of biodiversity conservation in Costa Rica. Global Environ Change 23:573-587

Benatti JH (1999) Unidades de Conservação e as populações tradicionais: uma análise jurídica da realidade brasileira. Novos Cadernos NAEA 2(2):107-126

Bensusan N (2006) Conservação da Biodiversidade em Áreas Protegidas. FGV, Rio de Janeiro, p 175

Benz A (2010) Multilevel Governance - Governance in Mehrebenensystemen. In: Benz A, Dose N (eds) Governance - Regieren in Komplexen Regelsystemen. Eine Einführung, VS-Verlag, Wiesbaden, pp 111-135

Berkes F (2004) Paper prepared for the Panel "Knowledge for the Development of Adaptive Co-Management". Nancy J. Turner and Fikret Berkes, session organizers. IACSP '04, Oaxaca, Mexico, August 2004., pp 1-17

Berkes F (2006) From community-based resource management to complex systems: the scale issue and marine commons. Ecol Soc 11(1):45

Berkes F (2009) Evolution of co-management: role of knowledge generation, bridging organizations and social learning. J Environ Manag 90:1962-1702

Berkes F, George PJ, Preston RJ (1991) Co-management: the evolution in theory and practice of the joint administration of living resources. Alternatives 18:12-18

Bisaro A, Hinkel J, Kranz N (2010) Multilevel water, biodiversity and climate adaption governance: evaluating adaptive management in Lesotho. Environ Sci Policy 13:637-647

Bonham CA, Sacayin E, Tzi E (2008) Protecting imperiled "paper parks": potential lessons from the Sierra Chinajá, Guatemala. Biodivers and Conserv 17 (7):1581-1593

Brandon K (1995) People, parks, forests or fields. A realistic view of tropical forest conservation. Land Use Policy 12(2):137-144

Brito MCW (2003) Unidades de Conservação: Intenções e Resultados. Annablume, FAPESP, São Paulo, p 230

Brussard PF, Reed JM, Tracy CR (1998) Ecosystem management: what is it really? Landsc Urban Plann 40:9-20

Campolim M, Parada I, Yamaoka J (2008) Gestão participativa da visitação publica na comunidade do Marujá - Parque Estadual da Ilha do Carodoso. IF Sér Reg, São Paulo 33:39-49

Carlsson L, Berkes F (2005) Co-management: concepts and methodological implications. J Environ Manag 75:65-76

Constanza R, d'Arge R, de Groot R, Farber S, Grasso M, Hannon B, Limburg K, Naeem S, O'Neill RV, Paruelo J, Raskin RG, Sutton P, van den Belt M (1997) The value of the world's ecosystem services and natural capital. Nature 387:253-260

de Groot R, Wilson MA, Boumans RMF (2002) A typology for the classification, description and valuation of ecosystem functions, goods and services. Ecol Econ 41:393-408

de Souza Pimentel D, Magro TC (2011) The symbolic sphere and social representations of Serra da Tiririca State Park, Rio de Janeiro, Brazil. A esfera simbólica e representações sociais do Parque Estadual da Serra da Tiririca, Rio de Janeiro, Brasil. Revista Sociedade \& Natureza 23:275-283

Diegues AC (1994) O Mito Moderno da Natureza Intocada. NUPAUB, University of São Paulo, São Paulo, p 164

Diegues AC (1996) As Populações Humanas em Áreas Naturais Protegidas da Mata Atlântica. NUPAUB, University of São Paulo, São Paulo

Diegues AC, Nogara P (2005) O Nosso Lugar Virou Parque, 3rd edn. NUPAUP, University of São Paulo, São Paulo

Diegues AC, Vianna LP (1995) Conflitos Entre Populações Humanas e Unidades de Conservação da Mata Atlântica. NUPAUP, University of São Paulo, São Paulo, p 323

Dowie M (2005) Conservation Refugees. When protecting nature means kicking people out. Orion Magazine November/December., pp 16-27

Fabricius C, Folke C, Cundill G, Schultz L (2007) Powerless spectators, coping actors, and adaptive co-managers: a synthesis of the role of communities in ecosystem management. Ecol Soc 12(1):29
Fenno RF (1986) Observation, context and sequence in the study of politics. Am Polit Sci Rev 80(1):3-15

Ferreira LC (2004) Dimensões humanas da biodiversidade: mudanças sociais e conflitos em torno de áreas protegidas no Vale do Ribeira, SP, Brasil. Ambiente \& Sociedade 7(1):47-66

Ferreira LC, de Oliveira Siviero S, Vieira de Campos S, Castelo Branco Silveira P, de Oliveira VG, Vianna Mendes AB, de Oliveira Pinto A (2001) Conflitos sociais em áreas protegidas no Brasil: moradores, instituições e ONGs do Vale do Ribeira e Litoral Sul, São Paulo. Idéias 8(2):115-150

Fraser EDG, Dougill AJ, Mabee WE, Reed M, McAlphine P (2006) Bottom up and top down: Analysis of participatory processes for sustainability indicator identification as a pathway to community empowerment and sustainable environmental management. J Environ Manag 78:114-127

Gadelha C (2008) Proibido Trabalhar. Problema Socioambiental dos Filhos da llha do Cardoso/SP, PhD thesis in Anthropology. Unicamp, São Paulo

Geoghegan T (2002) Participatory Forest Management in the Insular Caribbean: Current Status and Progress to Date, CANARI Technical Report number 310 Caribbean Natural Resources Institute, Trinidad and Tobago

Ibama, WWF-Brasil (2007) Efetividade de Gestão das Unidades de Conservação Federais do Brasil: Implementação do Método Rappam - Avaliação Rápida e Priorização da Gestão de Unidades de Conservação. Edições Ibama, Brasília

Jones N, Clark JRA, Panteli M, Proikaki M, Dimitrakopoulos PG (2012) Local social capital and the acceptance of Protected Area policies: an empirical study of two Ramsar river delta ecosystems in northern Greece. J Environ Manag 96:55-63

Lima GS, Ribeiro GA, Gonçalvez W (2005) Avaliação da efetividade de manejo das unidades de conservação de proteção integral em Minas Gerais. Revista Árvore 29(4):647-653

Margerum RD (2008) A typology of collaboration efforts in environmental management. Environ Manage 41(4):487-500

Matta JR, Alavalapati JRR (2006) Perceptions of collective action and its success in community based natural resource management: an empirical analysis. Forest Pol Econ 9:274-284

Millennium Ecosystem Assessment (2005) Ecosystems and Human Well-being: Synthesis. Island Press, Washington, DC

Mittermeier RA, da Fonseca GAB, Rylands AB, Brandon K (2005) Uma breve história da conservação da biodiversidade no Brasil. Megadiversidade $1(1): 14-21$

Morsello C (2001) Áreas Protegidas Públicas e Privadas Seleção e Manejo. Fapesp, São Paulo, Annablume

Noble BF (2000) Institutional criteria for co-management. Marine Policy 24:69-77

Nordlund LM, Kliober U, Carter E, Riedmiller S (2013) Chumbe Island Coral Park - governance analysis. Maine Policy 41:110-117

Ostrom E (2005) Understanding Institutional Diversity. Princeton University Press, New Haven, $C T$

Paavola J (2008) Explaining Multi-Level Environmental Governance. SRI Papers (Online) number 10 (April). Sustainability Research Institute, University of Leeds, Leeds

Pahl-Wostl C (2009) A conceptual framework for analysing adaptive capacity and multi-level learning processes in resource governance regimes. Global Environ Change 19:354-365

Pahl-Wostl C, Holtz G, Kastens B, Knieper C (2010) Analyzing complex water governance regimes: the Management and Transition Framework. Environ Sci Policy 13:571-581

Parada IS (2004) Mudanças Socioambientais de Comunidades Caiçaras do Parque Estadual da Ilha do Cardoso. In: Enciclopédia Caiçara: O Olhar do Pesquisador, vol 1. Editora Hucitec, São Paulo

Plummer R, FitzGibbon J (2004) Some observations on the terminology in co-operative environmental management. J Environ Manag 70:63-72

Plummer R, FitzGibbon J (2007) Connecting Adaptive Co-Management, Social Learning, and Social Capital through Theory and Practice. In: Armitage D, Berkes F, Doubleday N (eds) Adaptive Co-Management: Collaboration, Learning and Multi-Level Governance. UBC Press, Vancouver

Pomeroy R (2007) Conditions for Successful Fisheries and Coastal Resources Co-Management: Lessons Learned in Asia, Africa, and the Wider Caribbean. In: Armitage D, Berkes F, Doubleday N (eds) Adaptive Co-Management: Collaboration Learning and Multi-Level Governance. UBC Press, Vancouver, pp 172-187

Prager K (2010) Local and regional partnerships in natural resource management: the challenge of bridging institutional levels. Environ Manage 46:711-724 
Pretty J (2003) Social capital and the collective management of resources. Science 302:1912-1914

Pretty J, Smith D (2003) Social capital in biodiversity conservation and management. Conserv Biol 18(3):631-638

Pretty J, Ward H (2001) Social capital and the environment. World Development 29(2):209-227

Puppim de Oliveira JA (2002) Implementing environmental policies in developing countries through decentralization: the case of protected areas in Bahia, Brazil. World Development 30(10):1713-1736

Rodrigues CL (2001) Limites do Consenso: Territórios polissêmicos na Mata Atlântica e a Gestão Medio Ambiental Participativa, Dissertation. University of São Paulo, São Paulo

Rylands AB, Brandon K (2005) Unidades de conservação brasileiras. Megadiversidade 1(1):27-35

Santilli J (2005) Socioambientalismo e Novos Direitos: Proteção Jurídica à Diversidade Biológica e Cultural. Peirópolis, São Paulo

Sarrasin B, Tardif J (2012) Ecotourism and natural resources in Dominica: co-management as an innovative practice. Téoros, Hors série 1:85-90

Schöne H (2005) Die teilnehmende Beobachtung als Datenerhebungsmethode in der Politikwissenschaft. Methodologische Reflexion und Werkstattbericht. In: Mey G, Mruck K (eds) Qualitative Sozialforschung - Methodologische Reflexionen und disziplinäre Anwendungen: Ausgewählte Beiträge aus dem Forum Qualitative Sozialforschung, Sonderheft Number 111., Historical Social Research 30(1):168-199

Schultz L, Duit A, Folke C (2011) Participation, adaptive co-management, and management performance in the World Network of Biosphere Reserves. World Development 39(4):662-671

Suich $\mathrm{H}$ (2013) The effectiveness of economic incentives for sustaining community based natural resource management. Land Use Policy 31:441-449

Vallejo LR (2002) Unidades de Conservação: uma discussão teórica à luz dos conceitos de território e de políticas públicas. Geographia 4(8):1-22

Wood D (1995) Conserved to death: are tropical forests being over-protected from people? Land Use Policy 12(2):115-135

WWF-Brasil, ICMBio (2012) Efetividade da Gestão das Unidades de Conservação Federais do Brasil Resultados de 2010. WWF, Brasília, p 72

doi:10.1186/2192-1709-3-6

Cite this article as: Schröter et al:: Multi-level governance through adaptive co-management: conflict resolution in a Brazilian state park. Ecological Processes 2014 3:6.

\section{Submit your manuscript to a SpringerOpen ${ }^{\circ}$ journal and benefit from:}

- Convenient online submission

- Rigorous peer review

- Immediate publication on acceptance

- Open access: articles freely available online

- High visibility within the field

- Retaining the copyright to your article

Submit your next manuscript at $\gg$ springeropen.com 